\title{
Effect of Carbon and Nitrogen Sources on the Growth, Reproduction and Ligninolytic Enzymes Activity of Dictyoarthrinium Synnematicum Somrith
}

\author{
Prasher IB ${ }^{*}$, Chauhan R \\ Mycology \& Plant Pathology Laboratory, Department of Botany, Panjab University, India
}

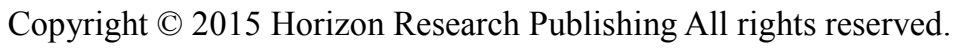

\begin{abstract}
The effect of different basal media, temperature, $\mathrm{pH}$, days of incubation, carbon and nitrogen sources was studied on growth, reproduction and ligninolytic enzymes production of Dictyoarthrinium synnematicum Somrith. The fungus reproduced by chlamydospores and produced maximum growth in Glucose-peptone medium. It produced chlamydospores only at $24^{\circ} \mathrm{C}$ and $\mathrm{pH}$ range of 5-9. The optimum mycelial growth rate was observed at $24^{\circ} \mathrm{C}$ and $\mathrm{pH}$ 5 after 16 days of incubation. It showed gradual increase in the production of Lignin peroxidase up to 30 days, Manganese peroxidase up to 18 days of incubation after which it decreased and Laccase up to 22 days. The optimum growth and laccase activity were attained in lactose supplemented medium whereas the highest Lignin peroxidase and Manganese peroxidase activity was observed with glucose. It produced chlamydospores with fructose, glucose, maltose, sucrose and xylose. Sodium nitrate is the best inorganic nitrogen source for growth. Resting spores were formed in inorganic and organic nitrogen sources used in basal medium. Ammonium phosphate and potassium nitrate supported highest activity of Lignin peroxidase whereas best Manganese peroxidase activity was exhibited with ammonium oxalate and laccase with sodium nitrate. The fungus did not express ligninolytic enzymes activity with any organic nitrogen source.
\end{abstract}

Keywords Dictyoarthrinium, Chlamydospores, Glucose-peptone Medium, Organic Nitrogen Source

\section{Introduction}

White rot fungi are unique in their ability to utilize lignin component of wood by using extracellular oxido-reductases enzymes [1-3] collectively known as ligninolytic enzymes. These ligninolytic enzymes mainly include Laccase, Lignin peroxidase (LiP) and Manganese peroxidase (MnP). The production of these enzymes by the fungi varies with different strains used and also depends on the composition of the medium used to grow these white rot fungi $[4,5]$. Many studies have been conducted to select new species of white rot fungi for their overproduction to be used at large scale for industrial use [6-8]. There are a few studies that have been initiated by different authors to know the effect of carbon and nitrogen sources on ligninolytic enzymes production of some white rot fungi $[9,10]$. The aim of the present study is to elucidate the significance of the influence of culture conditions (basal medium, temperature, $\mathrm{pH}$, days of incubation and carbon sources) on mycelial biomass production (growth) and reproduction and the influence of time period, different carbon and nitrogen sources on ligninolytic enzymes production of a new white rot fungus viz. Dictyoarthrinium synnematicum.

\section{Materials and Methods}

\section{Microorganism}

The specimen of Dictyoarthrinium synnematicum Somrith. was collected on an angiospermic twig from Bilaspur (Himachal Pradesh), India. It was isolated on Malt Extract Agar (MEA) medium (Malt Extract 20g, Agar agar 20g, distilled water to make $1000 \mathrm{ml}$ ) by single hyphal tip isolation method after four days and incubated for 8 days at $24^{\circ} \mathrm{C}$ in order to allow the growth on the surface of petri-dish. The stock cultures were maintained on the MEA plates at $\pm 4^{\circ} \mathrm{C}$ with periodic transfer.

\section{Basal Medium and Culture Conditions}

\section{Effect of Basal Media}

The fungus was grown in twelve different media viz. Raulin's, Richard's, Dox's, Coon's, Brown's I, Brown's II, Glucose-peptone, Glucose-nitrate, Czapek's I, Czapek's II, Asthana \& Hawker's and Elliot's medium (Table.1) 
Table 1. The chemical composition of various synthetic liquid basal media (g/litre) used for the growth (mg/25ml) of Dictyoarthrinium synnematicum .

\begin{tabular}{|c|c|c|c|c|c|c|c|c|c|c|c|c|}
\hline \multicolumn{13}{|c|}{ Basal Media } \\
\hline Chemicals & Raulin's & Richard's & Coon's & Dox's & \begin{tabular}{|l|} 
Glucose- \\
nitrate
\end{tabular} & $\begin{array}{l}\text { Glucose- } \\
\text { peptone }\end{array}$ & Brown's-I & $\begin{array}{l}\text { Brown's- } \\
\text { II }\end{array}$ & $\begin{array}{l}\text { Czapek's- } \\
\text { I }\end{array}$ & \begin{tabular}{|l} 
Czapek's- \\
II
\end{tabular} & \begin{tabular}{|l|} 
Asthana \\
\& \\
Hawker's
\end{tabular} & Elliot's \\
\hline Sucrose & 70 & 50 & - & 15 & - & - & - & - & 30 & 50 & - & - \\
\hline Glucose & - & - & - & - & 20 & 10 & 2.0 & 2.0 & - & - & 5.0 & 5.0 \\
\hline Maltose & - & - & 3.5 & - & - & - & - & - & - & - & - & - \\
\hline Potato starch & - & - & - & - & - & - & - & 10 & - & - & - & - \\
\hline Tartaric acid & 4.0 & - & - & - & - & - & - & - & - & - & - & - \\
\hline $\mathrm{Na}_{2} \mathrm{CO}_{3}$ & - & - & - & - & - & - & - & - & - & - & - & 1.06 \\
\hline $\mathrm{NH}_{4} \mathrm{NO}_{3}$ & 4.0 & - & - & - & - & - & - & - & - & - & - & - \\
\hline $\mathrm{NaNO}_{3}$ & - & - & - & 2.0 & - & - & - & - & 2.0 & 3.0 & - & - \\
\hline $\mathrm{KNO}_{3}$ & - & 10 & - & - & 2.5 & - & - & - & - & - & 3.5 & - \\
\hline Asparagine & - & - & 0.25 & - & - & - & 2.0 & 0.25 & - & - & - & 1.0 \\
\hline Peptone & - & - & - & - & - & 2.0 & - & - & - & - & - & - \\
\hline $\mathrm{KH}_{2} \mathrm{PO}_{4}$ & - & 5.0 & 1.25 & 1.0 & 5.0 & 1.0 & - & - & 1.0 & 1.0 & 1.75 & 1.36 \\
\hline $\mathrm{K}_{3} \mathrm{PO}_{4}$ & - & - & - & - & - & - & 1.25 & 1.25 & - & - & - & - \\
\hline $\mathrm{K}_{2} \mathrm{CO}_{3}$ & 0.6 & - & - & - & - & - & - & - & - & - & - & - \\
\hline KCL & - & 0.05 & - & 0.05 & - & - & - & - & 0.5 & - & - & - \\
\hline $\mathrm{MgSO}_{4} \cdot 7 \mathrm{H}_{2} \mathrm{O}$ & 0.4 & 2.5 & 0.5 & 0.05 & 0.25 & 0.5 & 0.75 & 0.75 & 0.5 & 0.25 & 0.75 & 0.5 \\
\hline $\mathrm{ZnSO}_{4} \cdot 7 \mathrm{H}_{2} \mathrm{O}$ & 0.07 & - & - & - & - & - & - & - & - & - & - & - \\
\hline $\mathrm{FeSO}_{4} \cdot 7 \mathrm{H}_{2} \mathrm{O}$ & 0.07 & - & - & 0.01 & - & - & - & - & 0.01 & 0.01 & - & - \\
\hline $\mathrm{FeCl}_{3} \cdot 6 \mathrm{H}_{2} \mathrm{O}$ & - & 0.02 & - & - & - & - & - & - & - & - & - & - \\
\hline$\left(\mathrm{NH}_{4}\right)_{2} \mathrm{SO}_{4}$ & 0.25 & - & - & - & 0.005 & - & - & - & - & - & - & - \\
\hline$\left(\mathrm{NH}_{4}\right)_{2} \mathrm{PO}_{4}$ & 0.6 & - & - & - & - & - & - & - & - & - & - & - \\
\hline
\end{tabular}

\section{Effect of temperature}

The effect of temperature on mycelial growth and reproduction was studied by growing the fungus on basal medium (glucose-peptone) at $16^{\circ} \mathrm{C}, 20^{\circ} \mathrm{C}, 24^{\circ} \mathrm{C}, 28^{\circ} \mathrm{C}$ and $32^{\circ} \mathrm{C}$ for 10 days. The temperature of the incubator was checked and recorded every day.

\section{Effect of $p H$}

A hydrogen-ion concentration range of 3.0-9.0 was selected to observe the growth and reproduction of the fungus with a difference of unit $\mathrm{pH}$. The $\mathrm{pH}$ of each aliquot was adjusted to a separate unit value aseptically with sterilized solution of $1 \mathrm{~N} \mathrm{HCl}$ and $1 \mathrm{~N} \mathrm{KOH}$ and checked over Digital $\mathrm{pH}$ Meter 813 and the flasks were incubated at the optimum temperature $\left(28^{\circ} \mathrm{C}\right)$ for 10 days.

\section{Effect of days of incubation}

A period of 30 days was selected to observe the optimum days of incubation for the growth, reproduction and enzyme production of the fungus at $28^{\circ} \mathrm{C}$ and $\mathrm{pH} 5.0$.

\section{Effect of carbon sources}

The effect of different carbon sources was evaluated by substituting the glucose by different carbon compounds (to provide $0.333 \mathrm{~g} / \mathrm{l}$ of carbon equivalent to $10 \mathrm{~g} / \mathrm{l}$ of glucose in the basal medium) at $28{ }^{\circ} \mathrm{C}$ and $\mathrm{pH} 5.0$ for 16 days of incubation. Control without additional carbon source was run in parallel.

\section{Effect of inorganic and organic nitrogen sources}

The effect of different nitrogen sources was evaluated replacing the peptone by different amino acids and inorganic nitrogen compounds $(2.0 \mathrm{~g} / \mathrm{l})$ at optimum conditions i.e. at $28^{\circ} \mathrm{C}$ and pH 5.0 in lactose supplemented basal medium for 16 days of incubation. Control without additional nitrogen source was run in parallel.

Incubation was carried out in $100 \mathrm{ml}$ Erlenmeyer flasks with $25 \mathrm{ml}$ of medium, which were inoculated with a $10 \mathrm{~mm}$ surface agar plug from 8 day old culture grown on MEA for all the experiments. Three replicates were maintained for each parameter for statistical studies. Cultures were filtered through Whatman filter paper No. 1 and dried overnight at $45-50{ }^{\circ} \mathrm{C}$ in a hot air oven. Dry weight of the mycelium was then determined using an electronic balance (Sartorius Analytical BL 210S). Culture filtrates were used as enzyme sources.

\section{Analytical Determinations}

Laccase activity was measured with $46 \mathrm{mM}$ Guaiacol in $0.1 \mathrm{M}$ sodium acetate buffer ( $\mathrm{pH} 4.5$ ) [11]. MnP activity was measured using $4 \mathrm{mM}$ Guaiacol as the substrate in $0.1 \mathrm{M}$ sodium succinate buffer $(\mathrm{pH} 4.5)$ at $30^{\circ} \mathrm{C}[12]$. LiP activity was assayed by the veratryl alcohol method using citrate-phosphate buffer with $\mathrm{pH} 4.5$ at $30{ }^{\circ} \mathrm{C}$ [12]. All 
enzymes were assayed spectrophotometrically, using a SHIMADZU UV spectrophotometer 1800.

\section{Statistical analyses}

All the experiments were performed in triplicates. The means of three replicate values for all data in the experiments obtained were tested in a one way ANOVA at $\mathrm{P}=0.05$ using PASW Statistics 18 software and Tukey's test was used to evaluate differences between treatments.

\section{Results}

\section{Effect of liquid culture media}

In the present study, Glucose-peptone medium (Glucose $10.0 \mathrm{~g} / \mathrm{l}$, Peptone $2.0 \mathrm{~g} / \mathrm{l}$, Potassium dihydrogen orthophosphate $1.0 \mathrm{~g} / 1$, Magnesium sulphate $0.5 \mathrm{~g} / 1$ and distilled water to make $1000 \mathrm{ml}$ ) was found to be an optimum medium for the growth of $D$. synnematicum. The growth rate was significantly greater in this medium followed by Elliot's medium than in other basal media. The fungus showed no growth in Raulin's medium (Fig.1). Mycelial growth was in the form of submerged as well as superficial, incomplete mycelial mat of small patches, dirty white and gelatinous in Richard's, Coon's, Czapek's-I \& II, Asthana \& Hawker's, Brown's-I \& II and Glucose-nitrate media, however, in Elliot's medium it was dirty white turning grayish white. It formed submerged, incomplete but almost complete, dirty white and gelatinous mycelial mat in Dox's medium. While in Glucose-peptone medium mycelial growth was complete and whitish grey. Hyphae were thin-walled, vacuolated, septate and profusely branched in all basal media. Along with thin-walled hyphae, dark brown hyphae were observed in Elliot's medium, which were septate at short intervals (Fig. 4c). In Brown's-I, Glucose-nitrate and Glucose-peptone media thin-walled chlamydospores also developed. In Glucose-peptone medium light brown hyphae were formed which aggregated to form synnemata like structures (Fig. 4e).

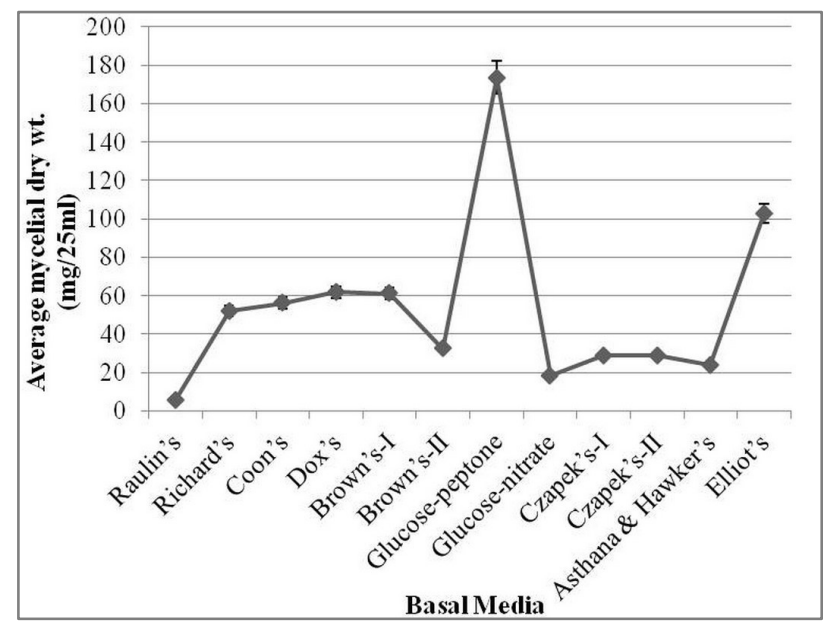

Figure 1. Growth rate of D. synnematicum in different basal media at $24^{\circ} \mathrm{C}$ after 10 days of incubation.

\section{Effect of temperature}

Dictyoarthrinium synnematicum exhibited optimum growth at $24^{\circ} \mathrm{C}$ (Fig. 2). The final $\mathrm{H}$-ion concentration of the basal medium did not changed significantly. At $16^{\circ} \mathrm{C}$ it produced least growth, with submerged and superficial, dull white, mycelium. The fungus produced dull white to grey complete mycelial mat at $24^{\circ} \mathrm{C}$ whereas at other temperatures it produced incomplete, submerged mycelial mat in the form of patches. It formed synnemata like structures and thin-walled chlamydospores in chains only at $24^{\circ} \mathrm{C}$ (Fig. 4d).

\section{Effect of $p H$}

The optimum $\mathrm{pH}$ for mycelial growth was found to be 5.0, whereas, at $\mathrm{pH} 3$ it did not show any growth (Fig. 3). Mycelium was in the form of submerged, dull white, incomplete, gelatinous mat at $\mathrm{pH}$ 4. Mycelial growth was in the form of submerged as well as superficial, dull white turning whitish grey, complete, gelatinous mat at $\mathrm{pH}$ 5-6 whereas from $\mathrm{pH}$ 7-9 it produced mycelial patches. It formed synnemata like structures from $\mathrm{pH}$ 5-9. However, no synnemata developed at $\mathrm{pH} 4$. The chlamydospores were formed at all $\mathrm{H}$-ion concentrations.

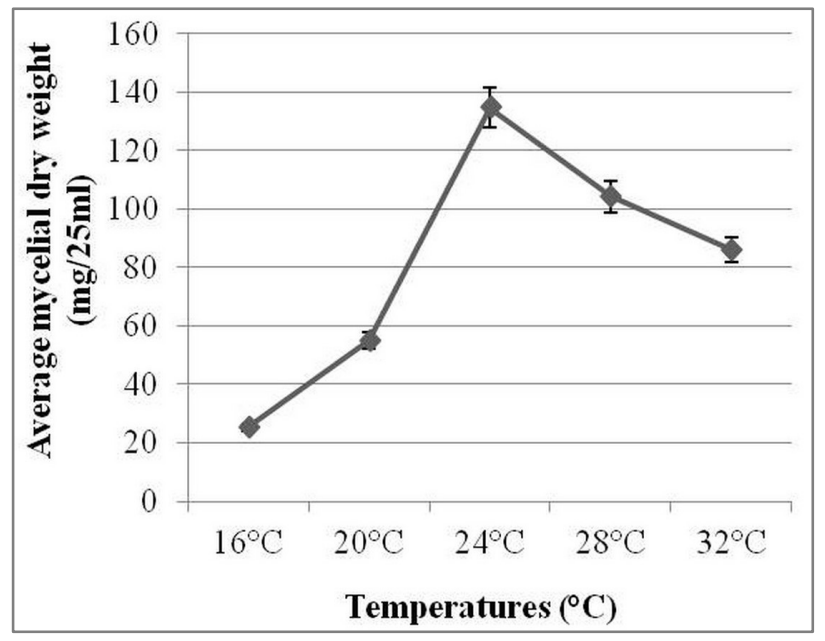

Figure 2. Effect of temperature on growth of $D$. synnematicum after 10 days of incubation at $\mathrm{pH} 5$.

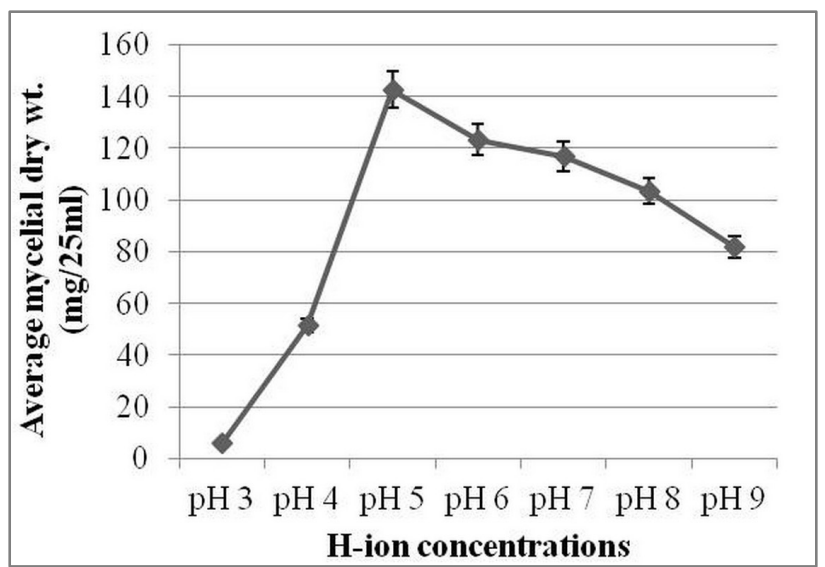

Figure 3. Effect of $\mathrm{pH}$ on growth rate of D. synnematicum after 10 days of incubation at $24^{\circ} \mathrm{C}$. 

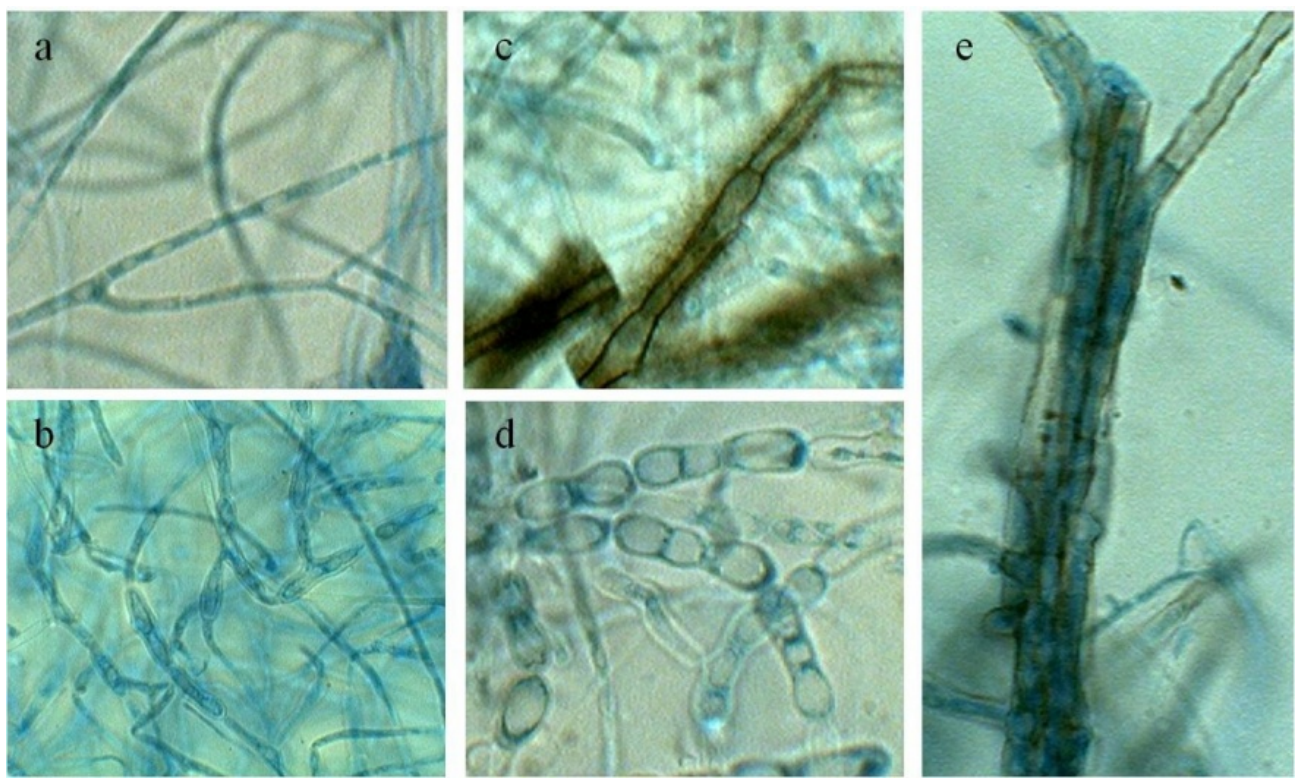

Figure 4. Microscopic characteristic of hyphae with different treatments: a- Thin-walled, septate and vacuolated hyphae. b,d- Thin-walled chlamydospores c- Septate brown colored hyphae formed in Elliot's medium. e- Developing synnemata in Glucose-peptone medium.

\section{Effect of days of incubation}

The maximum mycelial growth in terms of average mycelial dry weight (mg) was observed after 16 days after which it decreased. The final $\mathrm{pH}$ of the medium did not changed significantly up to optimum days of incubation, thereafter it started increasing. It showed gradual increase in the production of $\mathrm{LiP}$ up to 30 days of incubation. The highest $\mathrm{MnP}$ and Laccase activity was measured on $18^{\text {th }}$ and $22^{\text {nd }}$ day of incubation respectively, afterward which it decreased (Fig. 5). There was submerged, dull white, incomplete, gelatinous mycelial mat up to 8 days. Thereafter it formed complete mycelial mat whitish grey in color. Thin-walled, vacuolated, septate, branched hyphae developed up to 8 days of incubation (Figs. 4a,b). The fungus reproduced by chlamydospores (formed in chains) and developed whitish grey colored hyphae after 9 days of incubation which aggregated to form synnemata like structure

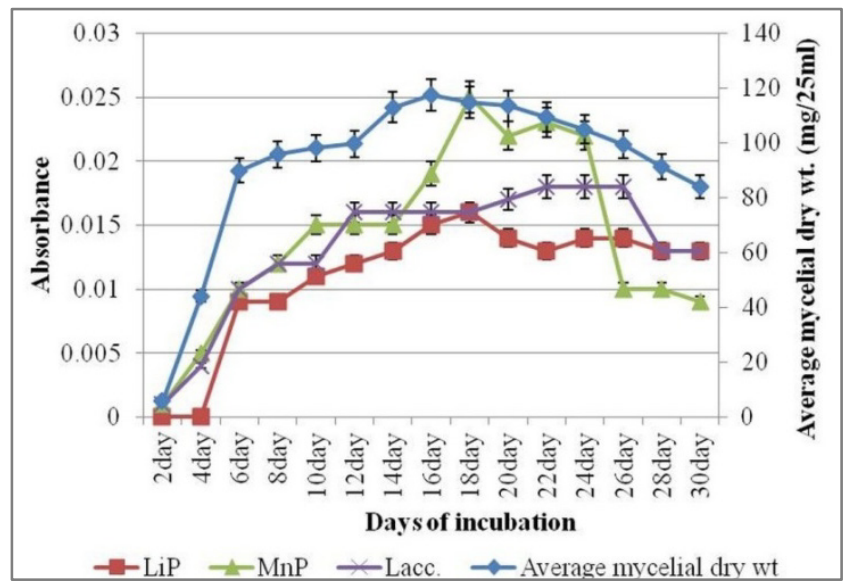

Figure 5. Growth rate and ligninolytic enzymes activity of $D$. synnematicum up to 30 days of incubation at $24^{\circ} \mathrm{C}$ and $\mathrm{pH} 5$.

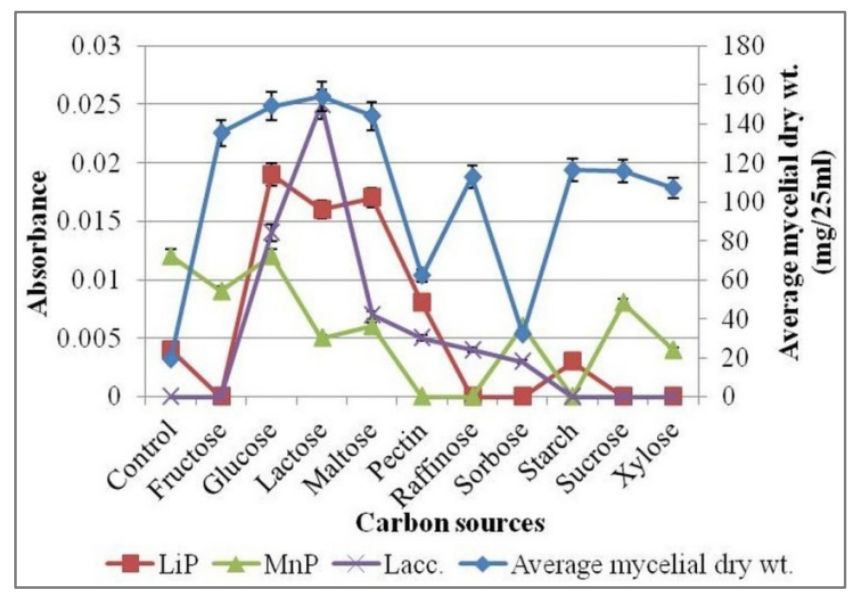

Figure 6. Effect of different carbon sources on growth and ligninolytic enzymes activity of D. synnematicum at $24^{\circ} \mathrm{C}$ and $\mathrm{pH} 5$ after 16 days of incubation.

\section{Effect of carbon sources}

The maximum mycelial growth was attained in lactose supplemented medium followed by glucose, maltose and fructose. The least growth was found in pectin and sorbose containing medium (Fig. 6). The final $\mathrm{pH}$ of the medium containing lactose, pectin and starch as carbon source changed significantly. The highest Laccase activity was measured in lactose followed by glucose whereas activity was found to be nil in fructose, starch, sucrose and xylose. $\mathrm{MnP}$ activity was observed to be maximum in glucose followed by fructose and sucrose. No $\mathrm{MnP}$ activity was observed in pectin, raffinose and starch and least activity was measured in lactose and xylose. The highest LiP activity was expressed in glucose, maltose and lactose. The fungus did not express LiP activity with fructose, raffinose, sorbose, sucrose and xylose (Fig. 6). The enzyme activities obtained show that the MnP enzyme is predominant in this isolate as 
compared to LiP and Laccase. Hyphae were thin-walled, profusely branched, septate and vacuolated; whitish grey hyphae formed synnemata like structures in control, glucose, lactose and starch. Microscopic studies revealed that it produced chlamydospores in selected carbon sources viz: fructose, glucose, maltose, sucrose and xylose (Fig. 7). No chlamydospores developed in control, lactose, pectin, raffinose, sorbose and starch.

\section{Effect of nitrogen sources:}

Sodium nitrate followed by potassium nitrate among the inorganic \& organic nitrogen sources used in basal medium exhibited maximum growth rate (Fig. 8). It did not grow in basal media containing ammonium acetate, sodium nitrite, L- $\alpha$ - amino n-butyric acid, L-cystine, L-cysteine HCL, DL-tryptophan and L-tyrosine as nitrogen source (Fig. 9). Dictyoarthrinium synnematicum exhibited highest activity of LiP with ammonium phosphate and potassium nitrate whereas the activity was not observed in ammonium chloride. The maximum MnP activity was found in ammonium oxalate, followed by potassium nitrate and it was absent in all other inorganic nitrogen containing basal medium. Laccase activity was found to be significantly high in sodium nitrate supplemented basal medium followed by ammonium oxalate (Fig. 8). Ammonium phosphate and potassium nitrate was found to be inhibitory for the expression of laccase activity. It did not express ligninolytic enzymes activity with any of the free amino acids. Mycelial growth was in the form of submerged as well as superficial, dull white, incomplete, mycelial patches in control, ammonium chloride, ammonium nitrate, ammonium chloride and ammonium phosphate and in all organic nitrogen sources \& in ammonium sulphate, potassium nitrate and sodium nitrate.
It did not reproduce in control, ammonium chloride, ammonium oxalate, potassium nitrate, DL-serine HCL and DL-threonine whereas it developed chlamydospores in inorganic nitrogen viz. ammonium nitrate, ammonium phosphate, ammonium sulphate and sodium nitrate and organic nitrogen sources viz. DL-alanine, L-arginine, DL-aspartic acid, dihydroxy phenylalanine, L-glutamic acid, glycine, L-histidine HCL, hydroxyl proline, L-leucine, lysine, DL-methionine, L-ornithine HCL, DL-phenylalanine, L-proline and DL-valine (Fig. 7).

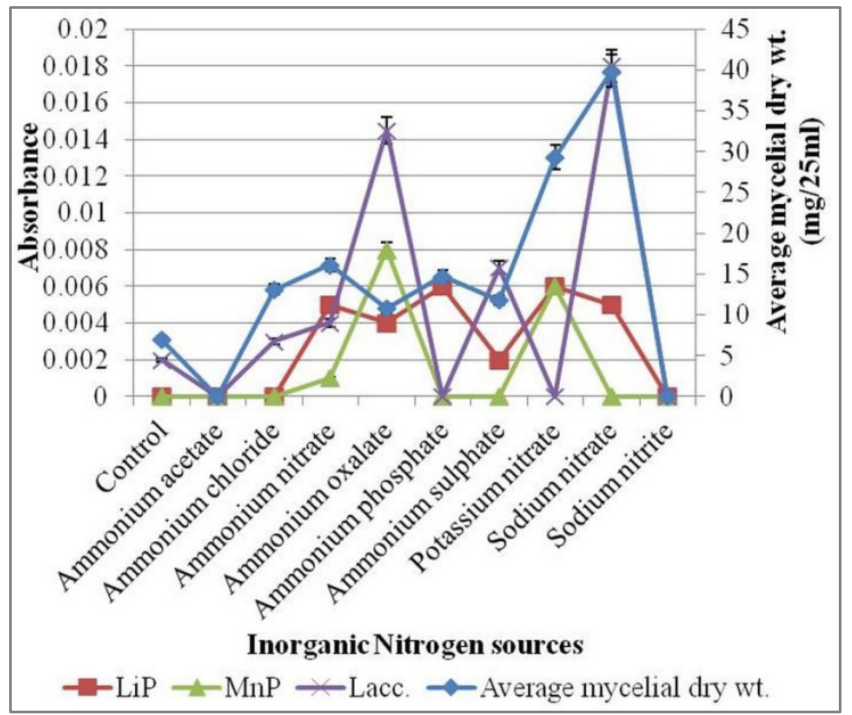

Figure 8. Effect of inorganic nitrogen sources on growth and ligninolytic enzymes activity of D. synnematicum at $24^{\circ} \mathrm{C}$ and $\mathrm{pH} 5$ after 16 days of incubation.
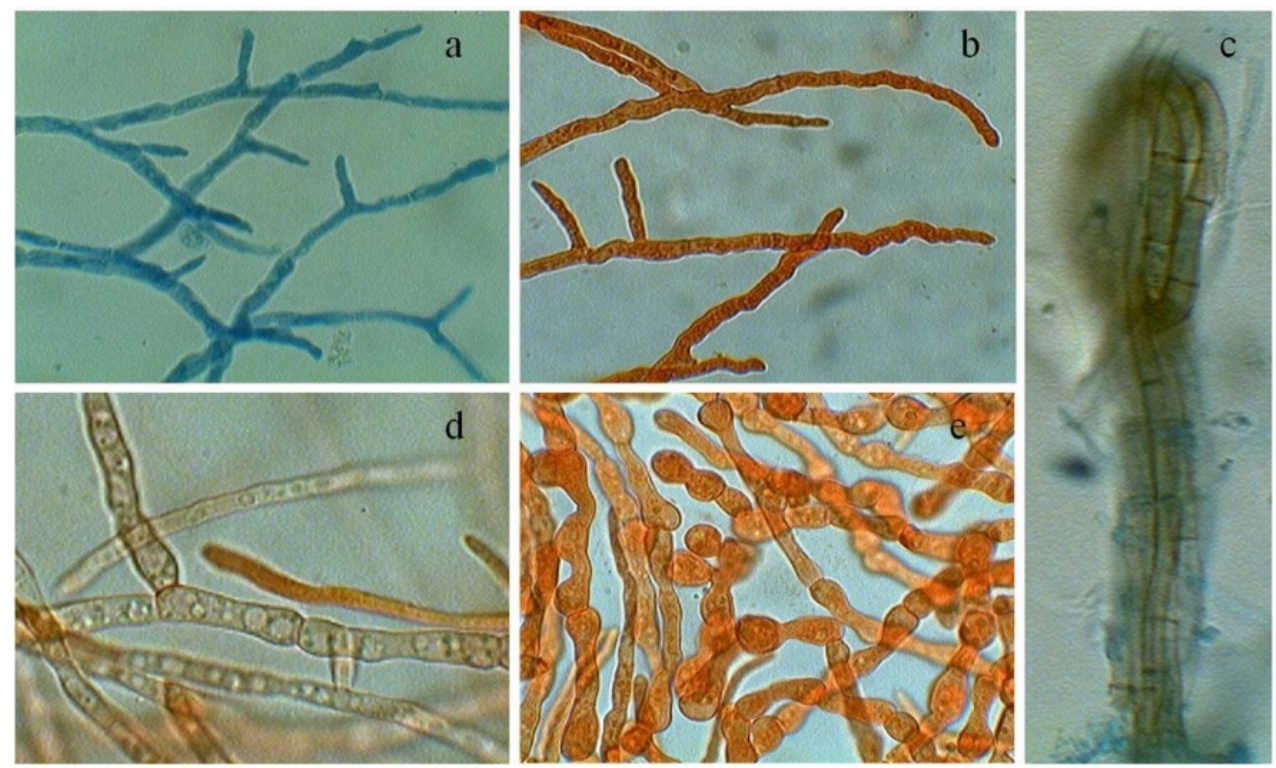

Figure 7. Microscopic characteristics: a,b- Thin-walled, branched hyphae developed in different carbon and nitrogen compounds. c- Thin-walled, whitish grey hyphae developed to form synnemata like structures in glucose, lactose, maltose, pectin and starch. d,e- Thin-walled chlamydospores in chains developed in carbon sources viz. fructose, glucose, maltose, sucrose and xylose; inorganic nitrogen sources viz. ammonium nitrate, ammonium phosphate, ammonium sulphate, sodium nitrate and in all organic nitrogen sources except DL-serine HCL and DL-threonine. 


\section{Discussion}

Optimization of the cultivation conditions for ligninolytic enzyme production has been extensively explored with selected organisms $[9,10,13,14]$. In the present study, the optimum temperature for the growth of $D$. synnematicum was found to be $24^{\circ} \mathrm{C}$ and optimum $\mathrm{pH}$ 5.0. The data on temperature and $\mathrm{pH}$ shows similarity with the patterns that were observed for Ustilago esculenta [15], in which the fungal growth was inhibited at $\mathrm{pH}-3$ and had prolonged lag phase at $16^{\circ} \mathrm{C}$. It gives optimum mycelial growth rate after 16 days of incubation.

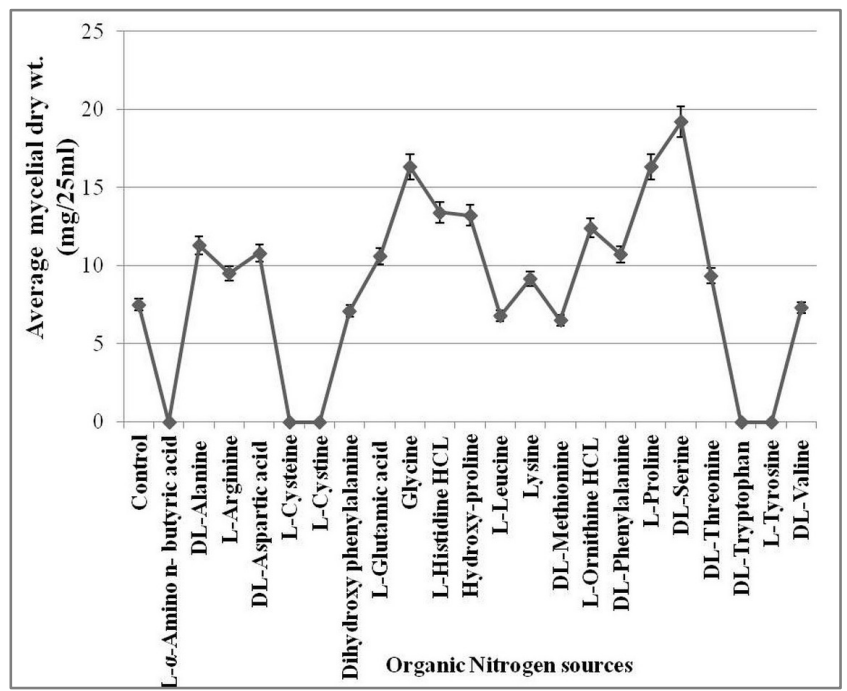

Figure 9. Effect of organic nitrogen sources on growth and ligninolytic enzymes activity of $D$. synnematicum at $24^{\circ} \mathrm{C}$ and $\mathrm{pH} 5$ after 16 days of incubation.

It produces thin-walled chlamydospores under different culture conditions. MnP activity increases and reaches its highest value on $18^{\text {th }}$ day of incubation, thereafter, it decreases whereas the highest value of Laccase activity is obtained on $22^{\text {nd }}$ day of incubation and there is a gradual increase in activity of LiP up to 30 days of incubation. The fungus shows maximum mycelial growth with lactose which is in accordance with other reports on the stimulating effect of lactose on mycelial growth of Tolyposporium penicillariae [16]. In utilizing L(-) sorbose, where it gives least growth, this fungus resembles many fungi like Phyllosticta spp. [17], Nigrospora oryzae [18], Alternaria alternate [19], Psathyerella atroumbonata [20]. Manganese peroxidase and Lignin peroxidase enzymes activities are found to be elevated in medium containing glucose as carbon source. There are reports in which the effect of carbon sources on ligninolytic enzyme production have been studied extensively in case of basidiomycetous fungi and these studies indicate that fungi show wide diversity in their response to produce ligninolytic enzymes with different carbon sources [21-24]. In Pleurotus sajor-caju Laccase activity was significantly higher in medium supplemented with fructose or glucose than that with lactose [25]. In contrast to that our findings reveal that D. synnematicum gives maximum Laccase activity with lactose followed by glucose whereas with fructose it does not express Laccase activity. In utilizing lactose for higher production of laccase, this fungus resembles with Pseudotrametes gibbosa, Cerrena unicolor and Fomes fomentarius [5]. Among the inorganic nitrogen sources and free amino acids used in basal medium it exhibits maximum growth rate in inorganic nitrogen source i.e. sodium nitrate. The fungus expresses highest activity of LiP with ammonium phosphate and potassium nitrate. In literature there are contradictory results for the effect of concentration and source of nitrogen on ligninolytic enzymes. Studies have shown that peptone has stimulating effect on ligninolytic activity of the fungi e.g. for Pleurotus ostreatus [26], Polyporus sanguineus [27] and for Laccase and $\mathrm{MnP}$ accumulation by Coriolopsis gallica [10]. On contrary to that our results show that sodium nitrate is the best nitrogen source for Laccase production by $D$. synnematicum whereas maximum $\mathrm{MnP}$ activity is expressed in ammonium oxalate. The production of ligninolytic enzymes i.e. Laccase, MnP and LiP depends not only on the species of fungi but also on the culture conditions, carbon and nitrogen sources and their concentrations [28-30].

The experimental results obtained so far with this fungus hints towards its potential application in important biotechnological applications. Further studies are in progress in this direction.

\section{Acknowledgements}

One of us (Radha Chauhan) acknowledges the Department of Science and Technology, Govt. of India, for the financial support in the form of fellowship under PURSE grant during the course of the study and to UGC for grant-in-aid under DRS-III programme. We are also thankful to the Chairperson, Department of Botany, Panjab University, for providing the facilities used during part of the experiments in this study.

\section{REFERENCES}

[1] A. Leonowicz, N. S. Cho, J. Luterek, A. Wilkolazka, M. Wojtas-Wasilewska, A. Matuszewska, M. Hofrichter, D. Wesenberg, J. Rogalski. Fungal laccase: properties and activity on lignin, J. Basic Microbiol., Vol. 41 No. 3-4, $185-227,2001$.

[2] A. T. Martinez, M. Speranza, F. J. Ruiz-Duenas, P. Ferreira, S. Camarero, F. Guillen, M. J. Martinez, A. Gutierrez, J. C. del Rio. Biodegradation of lignocellulosics: microbial, chemical and enzymatic aspects of the fungal attack of lignin, International Microbiology, Vol. 8, 195-204, 2005.

[3] T. K. Lundell, M. R. Mäkelä, K. Hildén. Lignin-modifying enzymes in filamentous basidiomycetes- ecological, functional and phylogenetic review, Journal of Basic Microbiology, Vol. 50, 5-20, 2010.

[4] D. Moldes, M. Lorenzo, M. A. Sanroman. Different proportions of laccase isoenzymes produced by submerged 
cultures of Trametes versicolor grown on lignocellulosic wastes, Biotechnol. Lett., Vol. 26, 327-330, 2004.

[5] V. Elisashvili, E. Kachlishvili. Physiological regulation of laccase and manganese peroxidase production by white-rot Basidiomycetes, Journal of Biotechnology, Vol. 144, 37-42, 2009.

[6] W. Hailei, Y. Guangli, L. Ping, G. Yanchang, L. Juna, L. Guoshenga, Y. Jianming. Overproduction of Trametes versicolor laccase by making glucose starvation using yeast, Enzyme Microb. Technol., Vol. 45, 146-149, 2009.

[7] R. C. Bonugli-Santosa, L. R. Durrant, M. da Silva, L. D. Sette. Production of laccase, manganese peroxidase and lignin peroxidase by Brazilian marine-derived fungi, Enzyme Microb. Technol., Vol. 46, 32-37, 2010.

[8] G. Y. S. Mtui. Lignocellulolytic enzymes from tropical fungi: Types, substrates and applications, Scientific Research and Essays, Vol. 7 No. 15, 1544-1555, doi: 10.5897/SRE11.1812, 2012.

[9] N. Mikiashvili, V. Elisashvili, S. Wasser, E. Nevo. Carbon and nitrogen sources influence the ligninolytic enzyme activity of Trametes versicolor, Biotechnology Letters, 27, 955-959, doi 10.1007/s10529-005-7662-x, 2005.

[10] N. Kenkebashvili, V. Elisashvili, S. P. Wasser. Effect of carbon, nitrogen sources, and copper concentration on the ligninolytic enzyme production by Coriolopsis gallica, Journal of Waste Conversion, Bioproducts and Biotechnology, Vol. 1 No. 2, 22-27, doi: 10.5147/jpgs.2012.0100, 2012.

[11] M. P. Coll, J. M. F. Abalos, J. R. Villanueva, R. Santamaria, P. Perez. Purification and characterization of phenoloxidase (Laccase) from the lignin-degrading basidiomycete PM I (CECT 2971), Applied and Environmental Microbiology, Vol. 59, 2607-2613, 1993.

[12] M. M. Atalla, H. K. Zeinab, R. H. Eman, A. Y. Amani, A. A. E. A. Abeer. Screening of some marine-derived fungal isolates for lignin degrading enzymes (LDEs) production, Agriculture and Biology Journal of North America, Vol. 1 No. 4, 591-599, 2010 .

[13] S. Trupkin, L. Levin, F. Forchiassin, A. Viale. Optimization of a culture media for ligninolytic enzyme production and synthetic dye decolorization using response surface methodology, J. Ind Microbiol. Biotechnol., Vol. 30, 682-690, 2003.

[14] E. Kachlishvili, M. J. Penninckx, N. Tsiklauri, V. Elisashvili. Effect of nitrogen source on lignocellulolytic enzyme production by white-rot basidiomycetes under solid-state cultivation, World Journal of Microbiology \& Biotechnology, doi: 10.1007/s11274-005-9046-8, 2005.

[15] K. R. Chung, D. D. Tzeng. Nutritional Requirements of the Edible Gall-producing Fungus Ustilago esculenta, Journal of Biological Sciences, Vol. 4 No. 2, 246-252, 2004.

[16] S. Singh. Studies on the nutrition of some members of Ustilaginales, Ph. D. Thesis, Panjab University, Chandigarh, India, 1979.

[17] K. S. Bilgrami. The utilization of L-sorbose by some pathogenic species of Phyllosticta, Proc. Ind. Acad. Sci. (Sec.B) 57, 230-234, 1963.
[18] G. S. Rawla, S. K. Tandon. Nutritional requirements of fungi-I. Influence of different carbon compounds on the growth of Nigrospora oryzae, Indian Journal of Mycology and Plant Pathology, Vol. 7 No. 1, 72-73, 1977.

[19] S. Kumar, M. P. Tandon. Utilization of monosaccharides by Alternaria alternate, Indian Phytopathology, Vol. 31 No. 2, 232-233, 1978.

[20] S. G. Jonathan, I. O. Fasidi. Effect of carbon nitrogen and mineral sources on growth of Psathyerella atroumbonata (Pegler), a Nigerian edible mushroom, Food Chemistry, Vol. $50,397-401,2001$.

[21] V. Elisashvili, E. Kachlishvili, N. Tsiklauri, M. Bakradze. Physiological regulation of edible and medicinal higher basidiomycetes lignocellulolytic enzymes activity, Int. J. Med. Mushr., Vol. 4, 159-166, 2002.

[22] V. Elisashvili, M. Penninckx, E. Kachlishvili, M. Asatiani, G. Kvesitadze. Use of Pleurotus dryinus for lignocellulolytic enzymes production in submerged fermentation of mandarin peels and tree leaves, Enzyme Microb. Technol., Vol. 38, 998-1004, 2006.

[23] C. Galhaup, H. Wagner, B. Hinterstoisser, D. Haltrich. Increased production of laccase by the wood-degrading basidiomycete Trametes pubescens, Enzyme Microb. Technol., Vol. 30, 529-536, 2002.

[24] P. Wang, X. Hu, S. Cook, M. Begonia, K. S. Lee, H. M. Hwang. Effect of culture conditions on the production of ligninolytic enzymes by white rot fungi Phanerochaete chrysosporium (ATCC 20696) and separation of its lignin peroxidise, World J. Microbiol. Biotechnol., Vol. 24, 2205-2212, 2008.

[25] F. Bettin, Q. Montanari, R. Calloni, T. A. Gaio, M. M. Silveira, A. J. P. Dillon. Production of laccases in submerged process by Pleurotus sajor-caju PS-2001 in relation to carbon and organic nitrogen sources, antifoams and Tween 80, J. Ind. Microbiol. Biotechnol., Vol. 36, 1-9, 2008.

[26] N. Mikiashvili, S. P. Wasser, E. Nevo, V. Elisashvili. Effects of carbon and nitrogen sources on Pleurotus ostreatus ligninolytic enzyme activity, World J. Microbiol. Biotechnol., Vol. 22, 999-1002, 2006.

[27] P. K. Bajwa, D. S. Arora. Comparative production of ligninolytic enzymes by Phanerochaete chrysosporium and Polyporus sanguineus, Can. J. Microbiol., Vol. 55, 1397-1402, 2009.

[28] S. R. Couto, E. Rosales, M. Gundin, M. A. Sanroman. Exploitation of wastes from the brewing industry for laccase production by two Trametes species, Journal of Food Engineering, Vol. 64, 423-428, 2004.

[29] A. N. Kapich, B. A. Prior, A. Botha, S. Galkin, T. Lundell, A. Hatakka. Effect of lignocellulose-containing substrate on production of ligninolytic peroxidases in submerged cultures of Phanerochaete chrysosporium ME-446, Enzyme and Microbial Technology, Vol. 34, 187-195, 2004.

[30] M. Stajić, L. Persky, D. Friesem, Y. Hadar, S. P. Wasser, E. Nevo, J. Vokojević. Effect of different carbon and nitrogen sources on laccase and peroxidases production by selected Pleurotus species, Enzyme Microb. Tech., Vol. 38 No. 1, 65-73, 2006. 